\title{
POTENTIAL ANTIDIABETIC ACTIVITIES OF FRACTIONS FROM PURIFIED EXTRACT OF LAWSONIA INERMIS LEAVES IN ALLOXAN-INDUCED DIABETIC MICE
}

\author{
MUS IFAYA ${ }^{1,5}$, IDA MUSFIROH ${ }^{2 *}$, SAHIDIN ${ }^{3}$, YASMIWAR SUSILAWATI ${ }^{4}$, GOFARANA WILAR ${ }^{1}$, SYAWAL \\ ABDURRAHMAN 6
}

${ }^{1}$ Department of Pharmacology and Clinical Pharmacy, Faculty of Pharmacy, Universitas Padjadjaran, ${ }^{2}$ Department of Pharmaceutical Analysis and Medicinal Chemistry, Faculty of Pharmacy, Universitas Padjadjaran, ${ }^{3}$ Faculty of Pharmacy, Universitas Halu Oleo Kendari, Southeast Sulawesi Indonesia, ${ }^{4}$ Department of Pharmaceutical Biology, Faculty of Pharmacy, Universitas Padjadjaran, ${ }^{5}$ Departemen of Pharmacy, Faculty of Science and Technology, Mandala Waluya Kendari High School of Health Science, Southeast Sulawesi Indonesia, ${ }^{6}$ Departement of Medical Laboratory Technology, Mandala Waluya Kendari High School of Health Science, Southeast Sulawesi Indonesia

*Email: ida.musfiroh@unpad.ac.id

Received: 08 Aug 2021, Revised and Accepted: 15 Aug 2021

ABSTRACT

Objective: This research was conducted to determine the potential antidiabetic activity fractions of purified extract Lawsonia inermis leaves in mice (Mus musculus) and identification of the compound.

Methods: The method included maceration, purification using ethanol and distilled water was followed by liquid-liquid extraction using ethyl acetate and magnesium sulfate as drying agents. Furthermore, the extract was analyzed using thin layer chromatography (TLC) for testing the purified extract. Fractionation using vacuum liquid chromatography, antidiabetic activity test of fractions at dose $100 \mathrm{mg} / \mathrm{kgBW}$ with alloxan induced and compound identification by Liquid Chromatography-Mass Spectrometry (LC-MS/MS) using HPLC connected to a Q-TOF spectrometer equipped with an ESI source, with Phenomenon column C8, and methanol with $0.3 \%$ formic acid as solvent.

Results: The results showed that from the purification step of $L$. inermis leaves by vacuum liquid chromatography method, 7 fractions were obtained, i.e. A-G fractions. While the antidiabetic activity of fractions shown by decreasing blood sugar level in mice on the $15^{\text {th }}$ day were $64,75,73$, $73,57,45$ and $67 \%$, respectively. The identified compounds from each fraction were the ester groups namely 12-hydroxy-methyl abietate, 9,12octadecadienoic acid (Z,Z)-(2,2-dimethyl-1,3-dioxolan-4-yl)methyl ester, dehydromorroniaglycone, and (E)-hexadecyl-ferulate; the steroid group namely siraitic acid E; phenylpropanoid groups namely umbelliferone and bletilol $\mathrm{C}$, and the alkaloid groups namely moupinamide and valine.

Conclusion: L. inermis leaves had activity in lowering blood sugar levels. LC-MS/MS analysis revealed the presence of ester groups, steroid groups, phenylpropanoid groups and alkaloid groups. The presence of these compounds mostly contribute to antidiabetic activity.

Keywords: L. inermis, Fractions, Anti-diabetic, Liquid chromatography-mass spectrometry

(C) 2021 The Authors. Published by Innovare Academic Sciences Pvt Ltd. Thisis an open access article under the CCBYlicense (https://creativecommons.org/licenses/by/4.0/) DOI: https://dx.doi.org/10.22159/ijap.2021.v13s4.43824 Journal homepage: https://innovareacademics.in/journals/index.php/ijap

\section{INTRODUCTION}

Diabetes mellitus (DM) is a major health problem in the world. DM is a long-term condition of increased levels of glucose in the blood because the body cannot produce sufficient insulin or does not effectively use the insulin it produces. Insulin is an essential hormone in the body produced by the pancreas that converts glucose into energy. In addition, insulin also plays a role in fat and protein metabolism [1]. Prolonged insulin deficiency can cause damage to various organs of the body, especially the eyes, kidneys, nerves, heart, and blood vessels [2].

The prevalence of diabetes mellitus is continuously increasing worldwide. In 2019, there were 463million (9.3\%) people aged 20 to $79 \mathrm{y}$ diagnosed with diabetes. It is estimated that the number of sufferers will continue to increase to reach 578 million (10.2\%) in 2030 and reach 700 million (10.9\%) in 2045. Especially in Indonesia with around 10.3 million people with diabetes, which is the largest in the world after China (114.4 million people), India (72.9 million people), the United States (30.2 million people), Brazil (12.5 million people), and Mexico (12 million people), it is estimated that the prevalence will increase to 16.7 million people in 2045 [1]. Based on this, it is necessary to do prevention or treatment to improve the health status of each individual.

Most people in carrying out maintenance and improvement of health and treatment of disease, still use traditional medicine or plants with medicinal properties. One of the traditional medicines used is Lawsonia inermis $[3,4]$. Apart from being antidiabetic, pharmacologically, $L$. inermis has many activities, including analgesic, anti-inflammatory, antimalarial, antimicrobial, antifungal, antiviral, antiparasitic, anthelmintic, antifertility, tuberculostatic, hepatoprotective, antioxidant, anticancer, hypolipidemic, and immunomodulatory [5, 6]. The leaf part of the L. inermis plant is used traditionally, by boiling with water, and used as a medicine to relieve itching and ulcers due to increased blood sugar levels, and the leaves are also used as a healer for skin wounds [7]. This plant is reported to contain quinone compounds, phenylpropanoids, flavonoids, terpenoids, phenolics, fatty acids, steroids, tannins, gallic acid, mannitol, resins, fats, and mucilage [8-10]. Several studies also reported the chemical content of the leaves, namely 2 hydroxy 1,4 naphthoquinone 1,4 dihydroxy naphthalene, 1,4 naphthoquinone, 1,2 dihydroxy glucoyloxynaphthalene and 2 hydroxy 1,4 glucosyloxynaphthalene [11].

A previous report showed that the percentage reduction in blood glucose level of hydroalcoholic extract of L. inermis leaves at a dose $400 \mathrm{mg} / \mathrm{kg}$ in rats was $39.08 \%$ on day 21 [12]. Research by Antika et al. [13] showed that the ethanolic extract of L. inermis leaves at doses of $200 \mathrm{mg} / \mathrm{kg} \mathrm{BW}, 400 \mathrm{mg} / \mathrm{kg} \mathrm{BW}$ and $600 \mathrm{mg} / \mathrm{kg}$ BW could reduce blood glucose levels in rats during $28 \mathrm{~d}$ of administration. In addition, the results of research by Zahara et al. [14] showed that administration of the ethyl acetate fraction at a dose of $600 \mathrm{mg} / \mathrm{kg}$ BW from L. inermis leaves significantly reduced blood sugar levels in rats. Based on the several studies that have been carried out, many benefits can be obtained from the plant, but scientific information related to the potential antidiabetic activity fractions of purified extract $L$. inermis leaves is not yet available and scientifically proven for its chemical content to treat as antidiabetic

\section{MATERIALS AND METHODS}

\section{Chemical and reagents}

L. inermis leaves were collected from Lamonae Village, Wiwirano District, North Konawe Regency. The part used was the leaves. 
Determination was carried out in the laboratory of the School of Life Sciences and Technology, Bandung Institute of Technology, Indonesia.

The materials used were distilled water, $96 \%$ ethanol, ethyl acetate, $\mathrm{MgSO}_{4}$, cerium sulfate, silica gel 60 0,063-0,200 mm (E. Merck), Silica gel 60 GF 254 (E. Merck), Silica gel 60 PF 254 (E. Merck), TLC silica gel 60 GF 254, alloxan monohydrate (Novomix®), Acarbose (pharmaceutical chemicals), mice (Swiss Webster strain), Sodium Carboxymethyl Cellulose (Na-CMC) (Pharmaceutical), $n$-hexane, acetone p. a, methanol p. a, chloroform p. a.

\section{Extraction}

The dry leaf powder L. inermis leaves which has been obtained was 3 kg. The sample was extracted by maceration method using $96 \%$ ethanol solvent until completely immersed for $3 \times 24 \mathrm{~h}$. This was carried out by the evaporation process and obtained $584.86 \mathrm{~g}$ of concentrated ethanol extract of $L$. inermis leaves. The yield of $L$. inermis leaves was obtained $19.49 \%$.

\section{Purified extract}

Chlorophyll contained in the sample was removed by adding methanol: distilled water (1:1), stirring and allowed to stand for 1x24 h. The precipitate, which is chlorophyll was separated from the filtrate. The 1.3 L chlorophyll-free filtrate was partitioned with ethyl acetate (1:1). Ethyl acetate phase was then added with $\mathrm{MgSO}_{4}$ as a drying agent, and filtered. The ethyl acetate phase was concentrated with a Rotary Vacuum Evaporator so that 40 grams of ethyl acetate extract was obtained. Furthermore, the extract was analyzed using thin-layer chromatography (TLC) to determine the separation pattern of each fraction that was separated using n-hexane eluent: ethyl acetate (1:1) [15].

\section{Fractionation by vacuum liquid chromatography}

Fractionation begins with packing the column. The chromatographic column was packed dry in a vacuum in order to obtain the maximum packing density. Ethyl acetate extract of L. inermis leaves as much as $20 \mathrm{~g}$ was put into a vacuum liquid chromatography column that had been prepared with silica gel as a stationary phase and then eluted using a mixed eluent of $n$-hexane and ethyl acetate in a row with the ratio of eluent used was n-hexane: ethyl acetate (8:2) 4 times, (7:3) 4 times, (5:5) 4 times, (3:7) 4 times, ethyl acetate (100\%) 2 times and methanol (100\%) 2 times, each made in $200 \mathrm{ml}$. Then the obtained fractions are accommodated in each container, evaporated to obtain dry fractions. The fractions were then TLC on the activated plate and then eluted with the appropriate eluent and observed under UV light 254 and $366 \mathrm{~nm}$ for grouping the fractions based on the similarity of the stains formed. The same spots were identified as having the same chemical components and could be made into a single fraction. All fractions resulting from fractionation using column chromatography were analyzed by TLC using the eluent, which gave the best separation. Prior to separation and purification using Vacuum Liquid Chromatography, the eluent was searched for the appropriate eluent using the eluent TLC technique that was most suitable to be used as a reference in separating using Vacuum Liquid Chromatography. Analysis of the results of the separation was carried out using a UV lamp and the reagent for the staining of cerium sulfate.

\section{Preparation of experimental animals}

This study was approved by the Animal Research Ethics Committee (AREC), Halu Oleo University Faculty of Medicine (AREC Reg. No: 1827b/UN29.20.1.2/PG/2020) and the experiments were conducted according to the ethical norms and AREC guidelines. The experimental animals used were mice (Swiss Webster strain) aged 2-3 mo with body weights ranging from 20-30 g BW. They were maintained at the Department of Pharmacy, Faculty of Science and Technology, Mandala Waluya University. The mice were housed at a temperature of $25{ }^{\circ} \mathrm{C}$ and fed on rodent pellets and water ad libitum. The animals were divided randomly into nine groups, each consisting of 5 animals. Group I as the positive control, Group II as negative control, group III-IX as the fractions testing group. Before treatment, all mice were fasted, then their fasting blood sugar levels were checked. Induction of diabetes in mice was carried out by administering alloxan monohydrate $(170 \mathrm{mg} / \mathrm{kg} \mathrm{BW}$ ) intraperitoneally. Blood sugar levels of mice were checked again $48 \mathrm{~h}$ after alloxan injection. The parameters for the success of induction are the increase in fasting blood glucose levels that exceed $125 \mathrm{mg} / \mathrm{dl}$ [16].

\section{Experimental design}

Group I: Alloxan treated control (170 mg/kg, ip)+acarbose 25 mg/kg BW. p.o

Group II: Alloxan treated control (170 mg/kg. ip)+Na-CMC $0.5 \%$

Group III: Alloxan (170 mg/kg. ip)+Fraction of A (100 mg/kg BW)

Group IV: Alloxan (170 mg/kg. ip)+Fraction B (100 mg/kg BW)

Group V: Alloxan (170 mg/kg. ip)+Fraction C (100 mg/kg BW)

Group VI: Alloxan (170 mg/kg. ip)+Fraction D (100 mg/kg BW)

Group VII: Alloxan (170 mg/kg. ip)+Fraction E (100 mg/kg BW)

Group VIII: Alloxan (170 mg/kg. ip)+Fraction F(100 mg/kg BW)

Group IX: Alloxan (170 mg/kg. ip)+Fraction G (100 mg/kg BW)

Blood samples were taken by cutting the tail of the mice and then measuring blood sugar levels using a glucometer for 5 replications on the first, third, seventh and fifteenth days.

\section{Statistical analysis}

Anti-diabetic test results data are interpreted in the form of averages and percentages. Significant differences between groups were tested using a One-way Analysis of Variance (ANOVA) and followed by post hoc LSD's test. Statistical analysis with p-value $<0.05$ is considered significant

\section{Identification of compounds using liquid chromatography-mass spectrometry (LC-MS/MS)}

The chemical constituents of the fractions were identified using LCMS/MS Method. LC-MS/MS is the only liquid chromatography technique with a mass spectrometer detector [17]. LC-MS/MS is used to separate several components of a compound or mixture of compounds based on their polarity (the working principle of chromatography), where after the mixture of compounds is separated, Then the pure compound will be identified based on its molecular weight. That data obtained is the molecular weight plus some charge and molecular weight solvent [18]. The liquid mobile phase pump flowed through the column to the detector. The sample is injected into the mobile phase stream using the injection method. In the column, there is a separation process for the components of the mixture, which results in differences in the strength of the interaction between the solutions in the stationary phase. The solution with less strong interaction with the stationary phase will leave the column first. On the other hand, when a strong solution interacts with the stationary phase, the solution will leave the column, which is then detected by the detector and recorded in the form of a chromatogram [19]. The LCMS/MS analysis method was performed using HPLC connected to a QTOF spectrometer equipped with an ESI source. Full scan method from $\mathrm{m} / \mathrm{z}$ to 1200 at $140 \mathrm{C}$ source temperature. Phenomenon HPLC column $5 \mu \mathrm{C} 8,(150 \times 2 \mathrm{~mm}$ i.d.) was used for analysis. The solvent used was methanol with $0.3 \%$ formic acid. Solvent delivered at a total flow rate of $0.1 \mathrm{ml} / \mathrm{min}$. Solvent run by isocratic elution. The MS spectrum was obtained in the positive ion mode. Drying gas temperature $\left(\mathrm{N}_{2}\right)$, gas flow rate and nebulization pressure $\left(\mathrm{N}_{2}\right)$ were set at $350{ }^{\circ} \mathrm{C}, 6 \mathrm{ml} / \mathrm{min}$, and 25 psi, respectively. Furthermore, about $0.5 \mathrm{~g}$ sample was diluted with methanol and filtered through a $0.22 \mu \mathrm{m}$ nylon filter before analysis. Volume $5 \mu \mathrm{l}$ fraction injected into the analytical column for analysis. Mass spectrometer analysis was performed to determine the mass fragmentation $(\mathrm{m} / \mathrm{z})$. The results of the mass spectrometry spectrum were compared with the similarity index (SI) numbers in the mass spectrometry liquid chromatography library. The similarity index number greater than $92 \%$ was considered to have the same fragmentation peak at the peak of liquid chromatography so that the peak is from the same as the compound read on liquid chromatography. The same value of the similarity index of fragmentation at the selected peak fragmentation of the compound with the lowest molecular weight as the analyzed peak fragmentation [20]. 


\section{RESULTS}

In vivo antidiabetic activity test on $L$. inermis leaves fraction with positive control of acarbose and negative control of Na-CMC as well as 7 fractions (A-G) were tested for $15 \mathrm{~d}$ of observation on test animals. The results of the in vivo anti-diabetic test on the leaf fraction of L. inermis are shown in table 1.

Table 1: Effect of fractions on fasting blood glucose in alloxan-induced diabetic mice

\begin{tabular}{|c|c|c|c|c|c|c|}
\hline \multirow[t]{2}{*}{ Group } & \multicolumn{6}{|c|}{ The mean level of blood glucose (mg/dl) } \\
\hline & FBGL & GLAI & $1^{\text {th }}$ day & $3^{\text {th }}$ day & $7^{\text {th }}$ day & $15^{\text {th }}$ day \\
\hline Group I (acarbose) & $65 \pm 4.4$ & $273 \pm 3.8$ & $250 \pm 10.0^{\wedge}$ & $173 \pm 25.1^{\wedge}$ & $91 \pm 15.6^{\wedge}$ & $72 \pm 3.0^{\wedge}$ \\
\hline Group II (Na CMC) & $68 \pm 3.5$ & $304 \pm 5.1$ & $267 \pm 2.5^{*}$ & $341 \pm 2.9^{*}$ & $406 \pm 13.9^{*}$ & $418 \pm 11.0^{*}$ \\
\hline Group III (Fraction A) & $62 \pm 2.5$ & $253 \pm 4.0$ & $152 \pm 17.0^{* \wedge}$ & $124 \pm 25.3^{* \wedge}$ & $103 \pm 26.1^{* \wedge}$ & $91 \pm 26.1^{* \wedge}$ \\
\hline Group IV (Fraction B) & $84 \pm 2.6$ & $275 \pm 4.3$ & $158 \pm 8.0^{* \wedge}$ & $101 \pm 7.0^{* \wedge}$ & $85 \pm 10.8^{* \wedge}$ & $68 \pm 7.0^{* \wedge}$ \\
\hline Group V (Fraction C) & $66 \pm 3.5$ & $308 \pm 6.2$ & $181 \pm 4.0^{* \wedge}$ & $150 \pm 3.0^{* \wedge}$ & $97 \pm 10.0^{* \wedge}$ & $82 \pm 5.0^{* \wedge}$ \\
\hline Group VI (Fraction D) & $82 \pm 1.7$ & $384 \pm 7.9$ & $275 \pm 6.9^{* \wedge}$ & $256 \pm 2.64^{* \wedge}$ & $119 \pm 1.7^{a^{* \wedge}}$ & $102 \pm 6.1^{* \wedge}$ \\
\hline Group VII (Fraction E) & $72 \pm 2.7$ & $233 \pm 17.7$ & $145 \pm 20.0^{* \wedge}$ & $125 \pm 9.0^{\mathrm{a}^{* \wedge}}$ & $116 \pm 4.6^{* \wedge}$ & $100 \pm 12.2^{* \wedge}$ \\
\hline Group VIII (Fraction F) & $68 \pm 2.7$ & $221 \pm 7.9$ & $166 \pm 3.5^{* \wedge}$ & $149 \pm 18.2^{* \wedge}$ & $131 \pm 16.5^{* \wedge}$ & $120 \pm 9.1^{* \wedge}$ \\
\hline Group IX (Fraction G) & $69 \pm 2$ & $317 \pm 12.2$ & $234 \pm 5.3^{* \wedge}$ & $210 \pm 14.7^{* \wedge}$ & $125 \pm 4.4^{* \wedge}$ & $103 \pm 3.0^{* \wedge}$ \\
\hline
\end{tabular}

*Significantly different to acarbose group (p<0.05); ^Significantly different to diabetic group (p,0.05) GLAI: Glucose Levels After Alloxan Induction; FBGL: Fasting Blood Glucose Levels. Data are expressed as means \pm SD of 5 independent experiments. The results of the anti-diabetic activity test on the fraction of $L$. inermis leaves obtained a significant decrease in blood glucose levels in the fractions $\mathrm{B}\left(68 \pm 7.0^{* \wedge}\right), \mathrm{C}\left(82 \pm 5.0^{* \wedge}\right)$ and $\mathrm{D}\left(102 \pm 6.1^{* \wedge}\right)$. The graph of measuring results of the average blood sugar level in mice can be seen in fig. 1 .

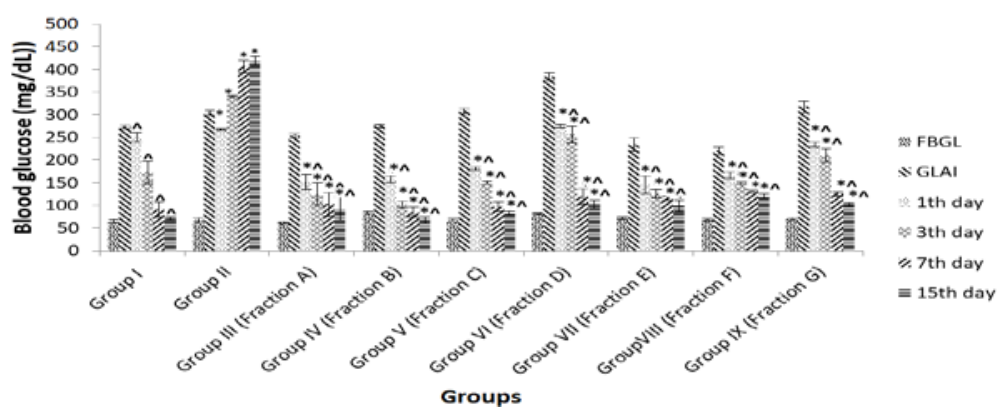

Fig. 1: Effect of fractions (A-G) of L. inermis leaves in alloxan-induced diabetic mice, ${ }^{*}$ Significantly different to acarbose group (p<0.05); ^significantly different to diabetic group $(p, 0.05)$ GLAI: Glucose Levels After Alloxan Induction; FBGL: Fasting Blood Glucose Levels. Data were expressed as means \pm SD of 5 independent experiments

Table 2: Identified of compounds contained fractions of L. inermis leaves using liquid chromatography-mass spectrometry (LC-MS/MS) method

\begin{tabular}{|c|c|c|}
\hline Fraction & Compounds & Observed m/z \\
\hline \multirow[t]{5}{*}{ A } & 12-Hydroxy-methyl abietate & 333.2396 \\
\hline & 9,12-Octadecadienoic acid (Z,Z)-(2,2-dimethyl-1,3-dioxolan-4-yl)methyl ester & 395.3126 \\
\hline & Candidate Mass $\mathrm{C}_{35} \mathrm{H}_{66} \mathrm{O}_{5}$ & 589.4806 \\
\hline & Candidate Mass $\mathrm{C}_{38} \mathrm{H}_{74} \mathrm{O}_{5}$ & 633.5429 \\
\hline & Candidate Mass $\mathrm{C}_{27} \mathrm{H}_{23} \mathrm{NO}_{6}$ & 458.1592 \\
\hline \multirow[t]{5}{*}{ B } & (E)-Hexadecyl-ferulate & 419.3127 \\
\hline & 9,12-Octadecadienoic acid (Z,Z)-(2,2-dimethyl-1,3-dioxolan-4-yl)methyl ester & 395.3128 \\
\hline & Candidate Mass $\mathrm{C}_{18} \mathrm{H}_{35} \mathrm{NO}$ & 282.2789 \\
\hline & Candidate Mass $\mathrm{C}_{24} \mathrm{H}_{45} \mathrm{NO}_{7}$ & 460.3265 \\
\hline & Candidate Mass $\mathrm{C}_{9} \mathrm{H}_{10} \mathrm{O}_{7}$ & 231.0499 \\
\hline \multirow[t]{5}{*}{$\mathrm{C}$} & (E)-Hexadecyl-ferulate & 419.3128 \\
\hline & 9,12-Octadecadienoic acid (Z,Z)-(2,2-dimethyl-1,3-dioxolan-4-yl)methyl ester & 395.3130 \\
\hline & Siraitic acid E & 457.2926 \\
\hline & Candidate Mass $\mathrm{C}_{38} \mathrm{H}_{74} \mathrm{O}_{5}$ & 633.5430 \\
\hline & Candidate Mass $\mathrm{C}_{42} \mathrm{H}_{72} \mathrm{O}_{5}$ & 657.5437 \\
\hline \multirow[t]{4}{*}{$\mathrm{D}$} & Dehydromorroniaglycone & 249.0757 \\
\hline & Candidate Mass $\mathrm{C}_{19} \mathrm{H}_{3} \mathrm{NO}_{14}$ & 469.9622 \\
\hline & Candidate Mass $\mathrm{C}_{21} \mathrm{H}_{3} \mathrm{NO}_{12}$ & 461.9725 \\
\hline & Candidate Mass $\mathrm{C}_{9} \mathrm{H}_{10} \mathrm{O}_{7}$ & 231.0495 \\
\hline \multirow[t]{5}{*}{$\mathrm{E}$} & Bletilol C & 463.1781 \\
\hline & Moupinamide & 314.1382 \\
\hline & Candidate Mass $\mathrm{C}_{9} \mathrm{H}_{10} \mathrm{O}_{7}$ & 231.0495 \\
\hline & Candidate Mass $\mathrm{C}_{18} \mathrm{H}_{22} \mathrm{O}_{15}$ & 479.1026 \\
\hline & Candidate Mass $\mathrm{C}_{19} \mathrm{H}_{3} \mathrm{NO}_{14}$ & 469.9622 \\
\hline \multirow[t]{4}{*}{$\mathrm{F}$} & Umbelliferone & 163.0386 \\
\hline & Candidate Mass $\mathrm{C}_{9} \mathrm{H}_{10} \mathrm{O}_{7}$ & 231.0498 \\
\hline & Candidate Mass $\mathrm{C}_{18} \mathrm{H}_{22} \mathrm{O}_{15}$ & 479.1032 \\
\hline & Candidate Mass $\mathrm{C}_{19} \mathrm{H}_{3} \mathrm{NO}_{14}$ & 469.9624 \\
\hline \multirow[t]{4}{*}{ G } & Umbelliferone & 163.0384 \\
\hline & Valine & 118.0858 \\
\hline & Candidate Mass $\mathrm{C}_{12} \mathrm{H}_{19} \mathrm{NO}_{12}$ & 370.0976 \\
\hline & Candidate Mass $\mathrm{C}_{10} \mathrm{H}_{19} \mathrm{NO}_{7}$ & 266.1233 \\
\hline
\end{tabular}



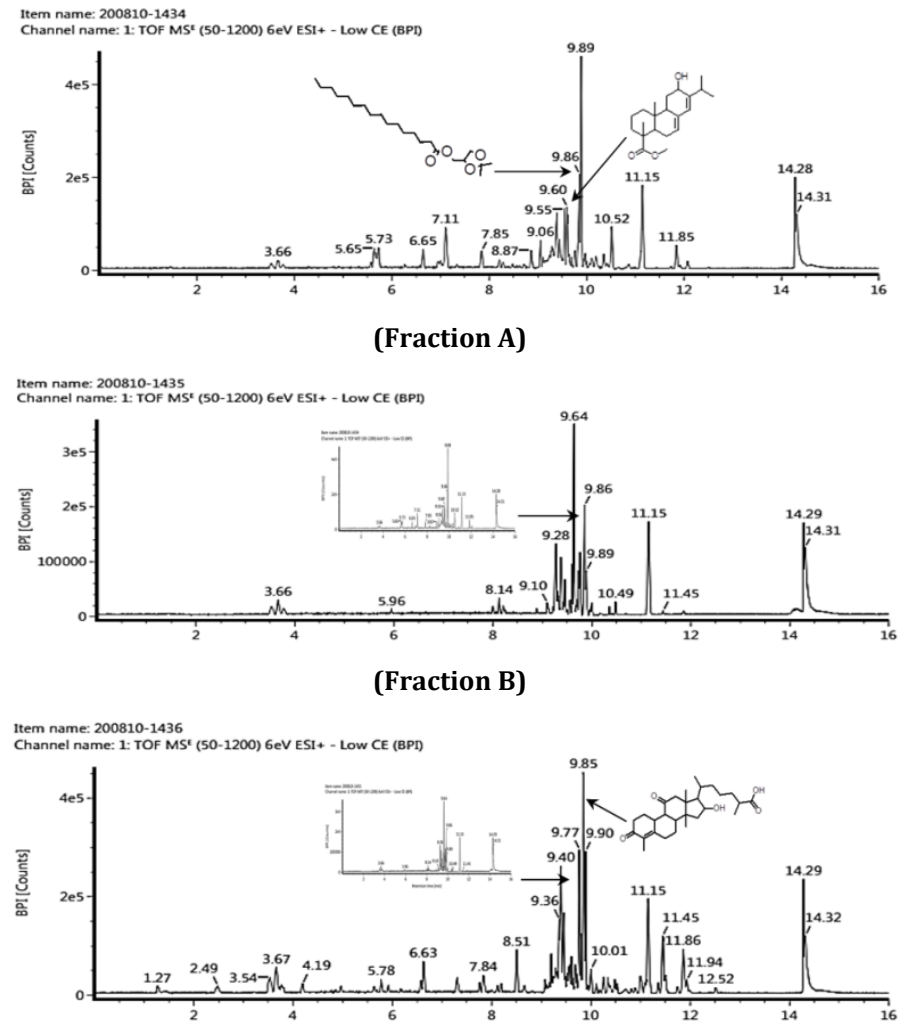

(Fraction C)

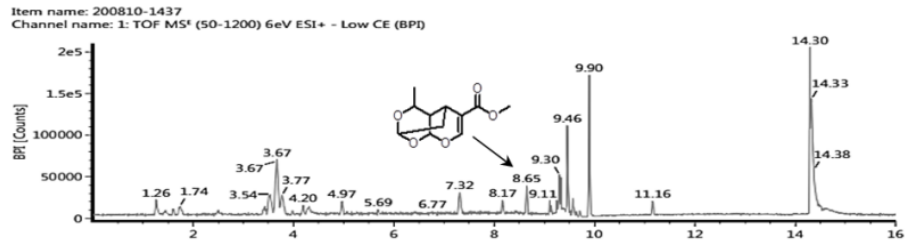

(Fraction D)

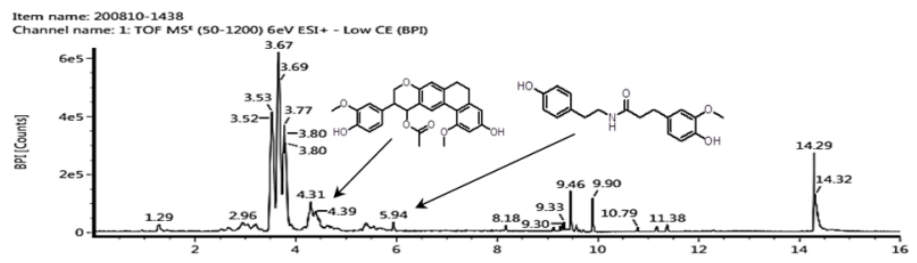

(Fraction E)

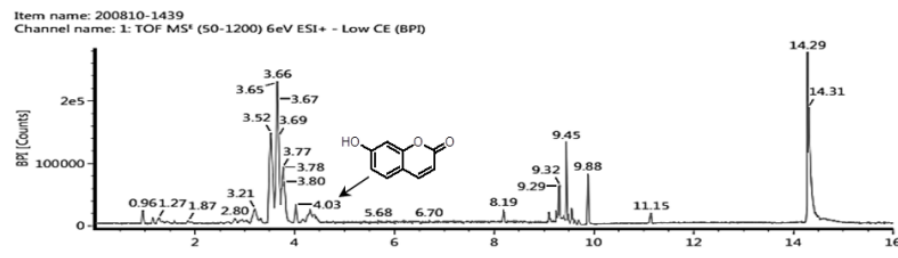

(Fraction F)

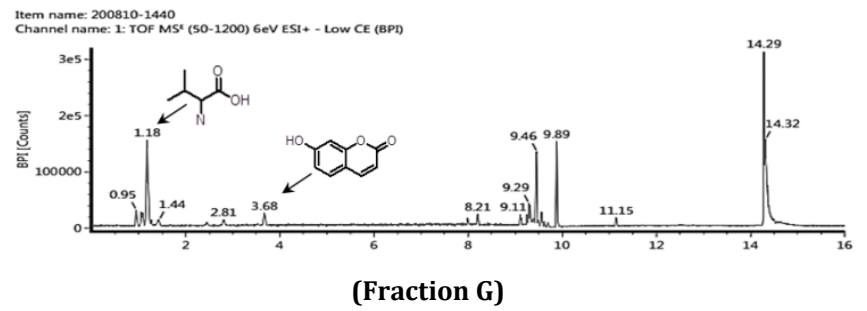

Fig. 2: Mass spectrums of the compounds from L. inermis leaves fractions (A-G) 


\section{DISCUSSION}

These studies were begun with measuring fasting blood glucose levels in all groups of mice. In table 1 it can be seen the effect of each fraction (AG) of $L$. inermis leaves on blood glucose levels after being given alloxan (170 mg/kg BW) intraperitoneally. Group I (acarbose treatment group), Group II (Na-CMC0.5\%), and Group IV-IX (100 mg/kg BW) had a significant increase in blood glucose levels. While the antidiabetic activity of the fractions indicated by a decrease in blood sugar levels in mice on day 15 were $64,75,73,73,57,45$, and $67 \%$, respectively.

The results showed that the average of fasting blood glucose levels in the positive control (acarbose) was $65 \pm 4.4 \mathrm{mg} / \mathrm{dl}$, the negative control group ( $\mathrm{Na}$ CMC $0.5 \%$ ) was $68 \pm 3.5 \mathrm{mg} / \mathrm{dl}$, and the fraction A to fraction G groups at a dose of $100 \mathrm{mg} / \mathrm{kg} \mathrm{BW}$ were $62 \pm 2.5,84 \pm 2.6$, $66 \pm 3.5,82 \pm 1.7,72 \pm 2.7,68 \pm 2.7$, and $69 \pm 2 \mathrm{mg} / \mathrm{dl}$, respectively. Then the mice were made in a diabetic condition by inducing alloxan monohydrate at a dose of $170 \mathrm{mg} / \mathrm{kg}$ BW for $48 \mathrm{~h}$. Blood glucose levels of mice were monitored for $3 \mathrm{~d}$ to see the effect of hyperglycemia. The observation showed that the blood glucose levels of the mice with hyperglycemia ranged between $221 \pm 7.9$ $384 \pm 7.9 \mathrm{mg} / \mathrm{dl}$. The hyperglycemic mice were then divided at random into 9 groups, consisting of 5 animals in each group. The results showed that reducing blood glucose levels between the acarbose group, Na-CMC group and the test group (A-G Fraction) which has the best effect on reducing blood sugar levels was Fraction B, C and D with a decrease value on day 15 , namely $68 \pm 7.0$, $82 \pm 5.0,102 \pm 6.1$ with a significant value $(\mathrm{p}<0.05)$ significantly different from the acarbose group and the Na CMC group.

According to [21] compounds from the polyphenol group, flavonoids, saponins/saponides, triterpenes, tannins, alkaloids, steroids, and cardiac glycosides act as antidiabetic with a mechanism of action. Increase glucose absorption, possess insulin-mimetic properties, inhibition of $\alpha$-amylase and $\alpha$-glucosidase and interactions with the insulin receptor that leads to the activation of biochemical cascades (PI3K and MAPK). Furthermore, research from [22] phenol and flavonoid compounds acting as antidiabetic by normalizing insulin levels, glucose uptake in peripheral tissues suppresses intestinal glucose uptake, prevents insulin resistance and significantly reversed the effects of fructose and insulin on lipid accumulation and there are alkaloid compounds that have activity anti-diabetic with insulinomimetic properties; inhibit carbohydrate digestion enzymes and prevention of oxidative stress.

Based on the data obtained, there are the same compounds in various fractions, the compound 9,12-0ctadecadienoic acid (Z,Z)(2,2-dimethyl-1,3-dioxolan-4-yl) methyl ester is an ester group compound found in fractions A, B and C. while for the compound (E)Hexadecyl-ferulate which is a compound with an ester functional group which from the analysis results obtained in fractions B and C. Ester group compounds are also obtained from fraction E, i.e. bletilol C. Esters are compounds derived from carboxylic acid derivatives that undergo oxidation reactions in the hydroxyl group where this carboxylic acid group is in the form of phenylpropanoid which is a cinnamic acid derivative compound. Cinnamic acid is derived from L-Phenylalanine through a deamination reaction. Hydrogenation of cinnamic acid produces P-Coumaric acid, which is an intermediate compound for the formation of phenylpropanoid derivatives, namely $p$-hydroxy sinapyl alcohol, coniferyl alcohol and sinapyl alcohol.

While for compounds derived from fractions $F$ and $G$ there is Umbelliferone compound which is a group of coumarin compounds. Coumarins have similarities to chlorogenic acid and rosmarinic acid can be formed from aromatic amino acids such as L-tyrosine. Modification of L-tyrosine will produce 4-hydroxyphenylpyruvic acid, then through several reaction steps such as reduction and dehydration, rosmarinic acid is produced. While chlorogenic acid can be formed through a substitution reaction between caffeine-CoA and quinic acid.

Compounds derived from fraction A were 12-hydroxy-methyl abietate which are derived from the diterpene group of terpenoid compounds composed of C5 units (isoprene). Farnesyl pyrophosphate (FPP) cation condensation with Isopentenyl pyrophosphate (IPP), followed by proton release to form geranylgeranyl pyrophosphate (GGPP). The next compound from the same compound group is triterpenes in fraction $\mathrm{C}$ is siraitic acid $\mathrm{E}$ which is composed of 6 units of C5 (isoprene). Triterpenoid biosynthesis is not through the addition of IPP to sesquiterpenoid. In the case of squalene, the precursor for triterpenoid and steroid formation is via the fusion of the tails of the two FPP units. While the compounds belonging to the alkaloid group were obtained from the $\mathrm{E}$ fraction, i.e. moupinamide and the fraction of $\mathrm{G}$ in the form of valine, both of these alkaloid compounds were derived from the amino acid tyrosine which was oxidized in the aromatic ring to produce dopamine compounds.

Furthermore, there are groups of compounds whose names and structures are still unknown from the analysis of the LCMS/MS compounds, including in fraction of $\mathrm{A}$ there are compounds with the molecular formula $\mathrm{C}_{35} \mathrm{H}_{66} \mathrm{O}_{5}, \mathrm{C}_{38} \mathrm{H}_{74} \mathrm{O}_{5}$, and $\mathrm{C}_{27} \mathrm{H}_{23} \mathrm{NO}_{6}$ Meanwhile, in fraction of $\mathrm{B}$, there are also alkaloid compounds $\mathrm{C}_{18} \mathrm{H}_{35} \mathrm{NO}$ and $\mathrm{C}_{24} \mathrm{H}_{45} \mathrm{NO}_{7}$. The same compound is present in various fractions among compounds with the molecular formula $\mathrm{C}_{9} \mathrm{H}_{10} \mathrm{O}_{7}$ derived from fractions of B, D, E and F. Then the compounds of the alkaloid group $\mathrm{C}_{19} \mathrm{H}_{3} \mathrm{NO}_{14}$ derived from fractions of $\mathrm{D}, \mathrm{E}$ and $\mathrm{F}$. In fractions of $\mathrm{E}$ and $\mathrm{F}$ the same compounds were obtained in the form of compounds with molecular formula $\mathrm{C}_{18} \mathrm{H}_{22} \mathrm{O}_{15}$. Other types of the compound that is different from other fractions are found in fraction of $\mathrm{C}$, i.e. compounds $\mathrm{C}_{38} \mathrm{H}_{74} \mathrm{O}_{5}$ and $\mathrm{C}_{42} \mathrm{H}_{72} \mathrm{O}_{5}$ and in fraction of $\mathrm{D}$ there are compounds of the alkaloid group, i.e. $\mathrm{C}_{21} \mathrm{H}_{3} \mathrm{NO}_{12}$, while in the $\mathrm{G}$ fraction there are also alkaloid group compounds identified by the molecular formula of the compound $\mathrm{C}_{12} \mathrm{H}_{19} \mathrm{NO}_{12}$ and $\mathrm{C}_{10} \mathrm{H}_{19} \mathrm{NO}_{7}$.

Moupinamide compound has activity as ethanolic hypoglycemic and antihyperglycemic activity [23]. Umbelliferone compound according to [24] umbelliferone as a potential antidiabetic herbal medicine in the management of diabetes. And research from [25] that valine compounds are biomarkers of type 2 diabetes and are associated with the hypoglycemic effect of sitagliptin.

\section{CONCLUSION}

The antidiabetic activities of fractions (A-G) from the purified extract of $L$. inermis leaves showed that the decreasing in blood sugar levels at a dose of $100 \mathrm{mg} / \mathrm{kg}$ BW occurred on the 15th day of administration with a decreasing in blood sugar level were 64,75 , $73,73,57,45$, and $67 \%$, respectively. LC-MS/MS analysis revealed the presence of ester groups, steroid groups, phenylpropanoid groups and alkaloid groups. The presence of these compounds mostly contribute to antidiabetic activity and based on the results of this study the $L$. inermis plant on the leaves can be used as a candidate for antidiabetic drugs.

\section{ACKNOWLEDGMENT}

The authors gratefully acknowledge Universitas Padjadjaran through the Research of Lecturer Competence 2021.

\section{FUNDING}

Nil

\section{AUTHORS CONTRIBUTIONS}

All the authors contributed equally.

\section{CONFLICTS OF INTERESTS}

The authors declare no potential conflicts of interest.

\section{REFERENCES}

1. Saeedi P, Petersohn I, Salpea P, Malanda B, Karuranga S, Unwin N. Global and regional diabetes prevalence estimates for 2019 and projections for 2030 and 2045: Results from the International Diabetes Federation Diabetes Atlas. 9th ed Diabetes Res Clin Practice. 2019;157:1-10.

2. Musso G, Gambino R, Bo S, Uberti B, Biroli G, Pagano G, Cassader M. Should nonalcoholic fatty liver disease be included in the definition of metabolic syndrome? A cross-sectional comparison with Adult Treatment Panel III criteria in nonobese nondiabetic subjects. Diabetes Care. 2008;31(3):562-8. doi: 10.2337/dc07-1526, PMID 18056890. 
3. Husni E, Suharty N, Atma APT. Characterization of simplicia and leaf extract of pacar kuku (Lawsonia inermis linn) and determination of total phenolic levels and antioxidant activity test. J Pharm Clin Sci. 2018;5:12-6.

4. Buddhadev SG, Buddhadev SS. Ayurvedic medicinal plant Lawsonia inermis Linn: A complete review. Pharm Sci Monit. 2016;7:240-8.

5. Kamal M, Jawaid T. Pharmacological activities of Lawsonia inermis Linn.: a review. Int J Biol Med Res. 2010;1(2):62-8. doi: 10.7439/ijbr.v1i2.56.

6. Akram M, Hamid A, Khalil A, Ghaffar A, Tayyaba N, Saeed A, Ali M, Naveed A. Review on medicinal uses, pharmacological, phytochemistry and immunomodulatory activity of plants. Int J Immunopathol Pharmacol. 2014;27(3):313-9. doi: 10.1177/ 039463201402700301.

7. Inawati I, Syamsuddin S, Winarno H. Effect of inai leaf extract (Lawsonia inermis linn.) against decreased glucose, total cholesterol and blood triglycerides on alloxan-induced mice. J Kimia Indones. 2006;1:71-7.

8. Chaudhary G, Goyal S, Poonia P. Lawsonia inermis linnaeus: A phytopharmacological review. Int J Pharm Sci Drug Res. 2010;2:91-8.

9. Li Q, Gao WQ Zhao YQ. Advances in studies on chemical constituents and biological activities of Lawsonia inermis. Zhongguo Zhong Yao Za Zhi. 2013;38(6):795-9. PMID 23717954.

10. Ojewunmi 0 . In vitro antioxidant, antihyperglycaemic and antihyperlipidaemic activities of ethanol extract of Lawsonia inermis Leaves. $\mathrm{Br} J$ Pharm Res. 2014;4(3):301-14. doi: 10.9734/BJPR/2014/6359.

11. Borade AS, Kale BN, Shete RV. A phytopharmacological review on Lawsonia inermis (Linn.). Int J Pharm Life Sci. 2011;2:536-41.

12. Surender S, Nishikant V, Ritu K, Prerna K, Rohit K, Yogendra KG. Safety and efficacy of hydroalcoholic extract from Lawsonia inermis leaves on lipid profile in alloxan-induced diabetic rats. An Int Q J Res Ayurveda. 2021;36:107-11.

13. Antika MA, Ilyas S, Sari MI. Effect of Lawsonia inermis Linn. Ethanol extract on the Superoxyde dismutase activity in hyperglycemic Rattus norvegicus. Indonesian J Med. 2017;02(2):79-85. doi: 10.26911/theijmed.2017.02.02.01.

14. Zahara F, Harahap U, Haro G. Physicochemical properties, phytochemical screening, and antihyperglycemic activity of inai (Lawsonia Inermis 1.) leaves active fraction on streptozotocininduced diabetic mice. Asian J Pharm Clin Res. 2018;11(5):68-71. doi: 10.22159/ajpcr.2018.v11i5.23504.

15. Juliawaty LD, Ra'idah PN, Abdurrahman S, Hermawati E, Alni A Tan MI, Ishikawa H, Syah YM. 5,6-Dihydro- $\alpha$-pyrones from the leaves of Cryptocarya pulchinervia (Lauraceae). J Nat Med.
2020;74(3):584-90. doi: 10.1007/s11418-020-01397-7, PMID 32207026.

16. Jelodar GA, Maleki M, Motadayen MH, Sirus S. Effect of fenugreek, onion and garlic on blood glucose and histopathology of pancreas of alloxan-induced diabetic rats. Indian J Med Sci. 2005;59(2):64-9. doi: 10.4103/00195359.13905. PMID 15738612.

17. Bowers LD. High-performance liquid chromatography/mass spectrometry: state of the art for the drug analysis laboratory. Clin Chem. 1989;35(7):1282-7. doi: 10.1093/clinchem/ 35.7.1288, PMID 2667792.

18. Ardrey RE. Liquid chromatography-mass spectrometry: an introduction. University of Huddersfield, Huddersfield, UK. John Wiley and Sons; 2003.

19. Supandi S, Harahap Y, Harmita H, Andalusia R. Analysis of 6mercaptopurine and 6-methylmercaptopurine in dried blood spots using liquid chromatography-tandem mass spectrometry and its application in childhood acute lymphoblastic leukimia patient. Asian J Pharm Clin. 2017;10:120-5.

20. Hanafi H, Irawan C, Rochaeni H, Sulistiawaty L, Roziafanto AN, Supriyono. Phytochemical screening, LC-MS studies and antidiabetic potential of methanol extracts of seed shells of archidendron bubalinum (Jack) I. C. nielson (Julang Jaling) from Lampung, Indonesia. Pharmacogn J. 2018;10:s77-82.

21. Mousinho NM, van Tonder JJ, Steenkamp V. In vitro antidiabetic activity of sclerocarya birrea and Ziziphus mucronata. Nat Prod Commun. 2013;8(9):1279-84. PMID 24273866.

22. van de Venter M, Roux S, Bungu LC, Louw J, Crouch NR, Grace OM, Maharaj V, Pillay P, Sewnarian P, Bhagwandin N, Folb P. Antidiabetic screening and scoring of 11 plants traditionally used in South Africa. J Ethnopharmacol. 2008;119(1):81-6. doi: 10.1016/j.jep.2008.05.031, PMID 18588966.

23. Sen P, Sahu K, Prasad P, Chandrakar S, Sahu RK, Roy A. Approach to phytochemistry and mechaniasm of action of plants having antidiabetic activity. UK J Pharm Biosci. 2016;4(1):82-120. doi: 10.20510/ukjpb/4/i1/90385.

24. Ramu R, Shirahatti PS, Swamy N, Zameer F, Dhananjaya BL, Nagendra PMN. Assessment of in vivo antidiabetic properties of umbelliferone and lupeol constituen of banana (Musa sp. var. Nanjangud rasa bale flower in hyperglycaemic rodent model. Plos One. 2016;11:1-17.

25. Liao X, Liu B, Qu H, Zhang L, Lu Y, Xu Y, Lyu Z, Zheng H. A high level of circulating valine is a biomarker for type 2 diabetes and is associated with the hypoglycemic effect of sitagliptin. Mediators Inflamm. 2019;2019:8247019. doi: 10.1155/ 2019/8247019. PMID 31827381. 